\title{
Enhancing wheat productivity and soil physical properties of water eroded agricultural land through integrated nutrient management
}

\author{
Murad Ali $^{1^{*}}$, Farmanullah Khan ${ }^{2}$, Subhanullah ${ }^{1}$, Wiqar Ahmad ${ }^{3}$, Muhammad Ishaq $^{1}$ \\ and Muhammad Saeed ${ }^{1}$ \\ ${ }^{1}$ Cereal Crops Research Institute (CCRI), Pirsabak Nowshera, KPK, Pakistan \\ ${ }^{2}$ Department of Soil \& Environmentạl Sciences, The Univẹrsity of Agriculturẹ, Peshawar \\ ${ }^{3}$ Department of Soil \& Environmentạl Sciences, The Univẹrsity of Agriculturẹ, AMK Campus Mardan, Pakistan
}

\begin{abstract}
Agricultural land in Pakistan is decreasing due to development of infrastructure and in order to feed its masses, agricultural activities are shifting towards sloping land where soil loss through surface runoff process is the sternest ecological threat to sustainable agriculture. Improving soil fertility and crop productivity through integrated nutrients management (INM) is a globally accepted practice. The reported study was conducted during 2014-15 for field investigations in the improvement of eroded soil's physical characteristics and crop productivity using integrated nutrients management techniques. The treatments contained combinations of NPK (\% of recommended

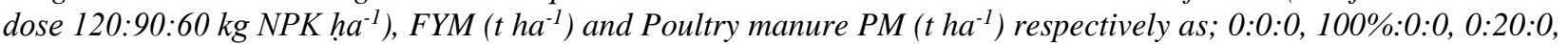
25\%:15:0, 50\%:10:0, 75\%:5:0, 0:0:10, 25:0:7.5, 50\%:0:5, 75\%:0:2.5, 0:5:2.5, 25\%:5:2.5, 50\%:5:2.5, 75\%:5:2.5. Results revealed that 50\%:5:2.5 combination of nutrient sources significantly $(p \leq 0.05)$ improved spike $m^{-2}$ (by $34 \%$ ), grains spike $e^{-1}$ (by 38\%) and grain yield (by 90\%) over the control treatment. Regarding soil physical properties, 0:20:0 combination reduced soil bulk density while improving available water, organic matter content and saturation water percentage at $0-15 \mathrm{~cm}$ soil depth. Positive correlation of soil organic matter was observed with available water holding capacity $(\dot{r}=0.92)$ and saturation percentage $(\dot{r}=0.93)$ while negatively co-related with soil bulk density $(\dot{r}=-0.96)$. It was concluded that chemical fertilizer's improvement in physical properties of eroded soil and the resultant production was significantly lagging behind that achieved with integrated nutrient management. Under the current experimental conditions, 50\%:5:2.5 combination of nutrient sources application restituted the physical properties of eroded soil and showed asset over rest of the INM and their unshared applications.
\end{abstract}

Keywords: Available water, bulk density, integrated nutrient management, organic, inorganic fertilizers, saturation percentage

\section{Introduction}

World's population has rapidly increased in the previous few decades and according to the latest reports, it will reach 9 billion by the year 2050 (UN; 2008). To feed the increasing population, growers are shifting to carry out agriculture activities on slopping and marginal lands also and that with unsuitable cultivation methods (Ali et al., 2007). These practices reward on site effects such as loss of soil particle, plant nutrients, changing of soil structure, reduction available in soil water and soil organic matter contents; all these factors are devastating soil productivity (Khan et al., 2004). Soil losses from sloppy field depend upon slope length and types, soil property, rainfall and soil management factor. The reported soil losses ranged from 2$104 \mathrm{t} \mathrm{ha}^{-1} \mathrm{yr}^{-1}$ in northern areas of Pakistan (Khan et al., 2001). In Swabi district the soil loss from silty clay loam texture, with 50\% slope was calculated as $356 \mathrm{t} \mathrm{ha}^{-1} \mathrm{yr}^{-1}$ without ground cover and no conservation measures (Allen, R., 1991). Bhatti and Zahid (1998) reported that grain yield of wheat crop decreased by $20 \%$ in severely eroded land as compared to slightly eroded soil.

Under these circumstances, the soil physical properties of water eroded land needs to be enhanced through joint use of mineral and organic nutrient sources to enhance crop yield on sustainable basis (Khan et al., 2007). Improving degraded soil quality is dependent upon the improvement of its physical, chemical and biological parameters (Ahmad et al., 2014). Initially the poor farming community used livestock by product as fuel and the crop nutrients demand was met from the recommended NPK fertilizer which provide specific nutrients to crop and improvement in soil physical parameters is negligible (Banning et al., 2008). Application of NPK fertilizers maintain yield potential, however, application of crop nutrients other than NPK

\footnotetext{
*Email: muradses@gmail.com
} 
Table 1: Physical properties of the composite soil under study

\begin{tabular}{lll}
\hline Property & Unit & Concentration \\
\hline Sand & $\%$ & 31.6 \\
Silt & $\%$ & 55.4 \\
Clay & $\%$ & 13 \\
Textural class & - & Silt loam \\
Organic matter contents & $\%$ & 0.69 \\
Saturation percentage & $\%$ & 33.28 \\
A W H C & $\%$ & 13.43 \\
Bulk density & $\mathrm{g} \mathrm{cm}^{-3}$ & 1.42 \\
\hline
\end{tabular}

Table 2: Effect of integrated plant nutrients on spike $\mathrm{m}^{-2}$, grains pike ${ }^{-1}$ and grain yield

\begin{tabular}{|c|c|c|c|}
\hline Treatment (NPK:FYM:PM) & Spike $\mathrm{m}^{-2}$ & Grains spike $^{-1}$ & Grain yield $\left(\mathrm{kg} \mathrm{ha}^{-1}\right)$ \\
\hline 0:0:0 & $201.7 \mathrm{f}$ & $45.6 \mathrm{e}$ & $2211 \mathrm{~g}$ \\
\hline 100\%:0:0 & $216.0 \mathrm{ef}$ & $47.8 \mathrm{de}$ & $2493 \mathrm{fg}$ \\
\hline 0:20:0 & $222.6 \mathrm{def}$ & $49.5 \mathrm{cde}$ & $2855 \mathrm{defg}$ \\
\hline $25 \%: 15: 0$ & $246.6 \mathrm{abcd}$ & $55.8 \mathrm{abcd}$ & 3544 abcd \\
\hline 50\%:10:0 & $258.0 \mathrm{abc}$ & $57.1 \mathrm{abc}$ & 3311 bcde \\
\hline $75 \%: 5: 0$ & $217.6 \mathrm{ef}$ & $50.6 \mathrm{cde}$ & $2738 \mathrm{efg}$ \\
\hline $0: 0: 10$ & $229.4 \mathrm{de}$ & 51.9 cde & 2991 cdef \\
\hline $25: 0: 7.5$ & $246.6 \mathrm{abcd}$ & $55.7 \mathrm{abcd}$ & $3597 \mathrm{abc}$ \\
\hline $50 \%: 0: 5$ & $262.9 \mathrm{a}$ & $57.1 \mathrm{abc}$ & $3878 \mathrm{ab}$ \\
\hline $75 \%: 0: 2.5$ & 233.8 cde & 53.5 bcde & 3042 cdef \\
\hline $0: 5: 2.5$ & 236.3 bcde & 53.5 bcde & 3253 bcde \\
\hline $25 \%: 5: 2.5$ & $261.0 \mathrm{ab}$ & $57.2 \mathrm{abc}$ & $3900 \mathrm{ab}$ \\
\hline $50 \%: 5: 2.5$ & $270.5 \mathrm{a}$ & $63.0 \mathrm{a}$ & 4206 a \\
\hline $75 \%: 5: 2.5$ & $266.4 \mathrm{a}$ & $61.5 \mathrm{ab}$ & $4066 \mathrm{a}$ \\
\hline $\operatorname{LSD}_{(p \leq 0.05)}$ & 26.55 & 9.19 & 739 \\
\hline
\end{tabular}

fertilizers are needed for degraded soil to enhance soil quality and crop production (Mussgnug et al., 2006). Development of soil yield parameters and physical properties mainly rests upon the enhancement of soil organic matter content and replenishment of nutrient reserves (Ahmad and Khan, 2014; Ahmad et al., 2014). In an experiment, Ahmad et al. (2017) reported 5 and 7\% increase in total soil porosity and available water content and $4 \%$ decrease in bulk density of the moderately degraded alfisols after four seasons applications of FYM $\left(20 \mathrm{tha}^{-1}\right), 50 \%$ lower than the recommended $\mathrm{N}$ and of the same as the recommended $\mathrm{P}$ and $\mathrm{K}$ doses. This study was conducted on water eroded agricultural soil $\left(34.72^{\circ} \mathrm{N}\right.$, $72.11^{\circ}$ E) at Swabi District of the Khyber Pakhtunkhwa province-Pakistan in 2014-2015 with the objective to provide a more realistic and feasible blend of the organic and inorganic nutrient sources for restoring the physical qualities and yield of the soils affected by water erosion.

\section{Material and Methods}

Experimental plot was selected on water eroded agricultural soil $\left(34.72^{\circ} \mathrm{N}, 72.11^{\circ} \mathrm{E}\right)$ at Swabi District of the Khyber Pakhtunkhwa province-Pakistan in 2014-2015.
A composite soil sample was obtained from $0-15 \mathrm{~cm}$ depth of the selected plot before sowing and was analyzed for the assessment of soil physical properties (Table 1).

The experimental trial was carried out in randomized complete block design (RCBD) replicated three times and treatment plot size of $3 \mathrm{~m} \times 5 \mathrm{~m}$. The treatments contained combinations of NPK (\% of recommended dose 120:90:60 kg NPK ha $\left.a^{-1}\right)$, FYM $\left(\mathrm{t} \mathrm{ha}^{-1}\right)$ and Poultry manure PM $\left(\mathrm{t} \mathrm{ha}^{-1}\right)$ respectively as; 0:0:0, 100\%:0:0, 0:20:0, 25\%:15:0, 50\%:10:0, 75\%:5:0, 0:0:10, 25:0:7.5, 50\%:0:5, 75\%:0:2.5, $0: 5: 2.5,25 \%: 5: 2.5,50 \%: 5: 2.5,75 \%: 5: 2.5$. All the organic fertilizer doses were applied to respective plots 15 days before sowing. Urea, DAP and SOP were used as sources for NPK, respectively. Nitrogen was applied in two splits, half at sowing whilst the other half at tillering stage. All $\dot{\mathrm{P}}$ and $\mathrm{K}$ doses were applied at the time of sowing. All other agronomic practices were uniformly applied.

Soil samples from each experimental plot after crop harvest were collected at $0-15 \mathrm{~cm}$ depth. Soil physical properties such as texture (Tagar and Bhatti, 1996), bulk density (Blake and Hartage, 1984), saturation percentage (Gardner, 1986) and available water holding capacity (Raza 
et al., 2003) from soil samples of each experimental plot were determined.

Data collected on crop agronomic characteristics and soil physical properties was subjected to analysis of variance (ANOVA) technique using Statistics 8.1 software. Mean values were compared using LSD (least significant difference) test at the $\mathrm{p} \leq 5 \%$ (Steel et al., 1997). Correlation of soil physical characteristics and organic matter content was determined using MS Excel.

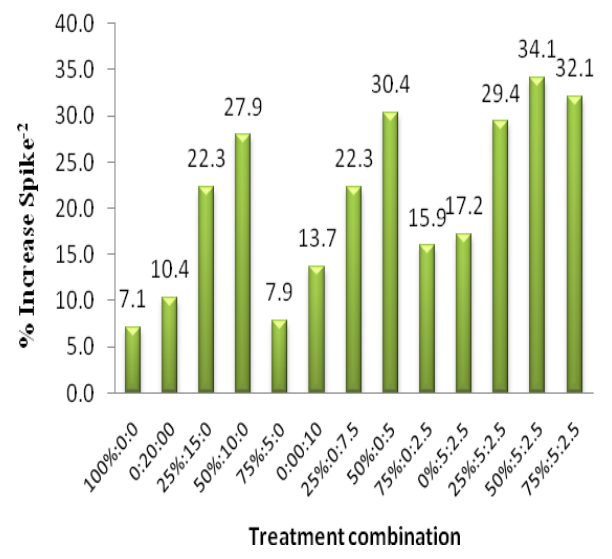

Figure 1: Percent increases in spike $\mathrm{m}^{-2}$ over control due to applied treatments

\section{Results and Discussion}

\section{Spikes $\mathrm{m}^{-2}$}

Combined application of organic and inorganic nutrient sources significantly improved spikes $\mathrm{m}^{-2}$ (Table 2). Maximum spikes $\mathrm{m}^{-2}$ (270) were produced with the use of $50 \%: 5: 2.5$ combination of NPK:FYM:PM as compared to control (201). Increase over the control (34\%) in spikes $\mathrm{m}^{-2}$ was recorded with the combined use of organic and inorganic fertilizers (Figure 1.). These findings were in close confirmation of the results of Bhatti (2006), who reported that joint use of organic and inorganic nutrient sources significantly improved spike $\mathrm{m}^{-2}$ as compared with application of either organic or inorganic fertilizers. In an earlier study, (Idrees et al., 2002) had investigated that organic fertilizers slowly release crop nutrients through the process of decomposition for improved crop performance throughout the growing season.

\section{Grains Spike ${ }^{-1}$}

Integrated use of organic and inorganic sources of nutrients had significantly enhanced grains spike ${ }^{-1}$ (Table
2). Higher grains spike ${ }^{-1}$ (63) were produced with application of 50\%:5:2.5 combination of NPK:FYM:PM, while lowest grains spike ${ }^{-1}(46)$ were produced in control plot. Joint use of organic and inorganic nutrient sources improved grains spike ${ }^{-1}$ by $38 \%$ over the control (Fig. 2). Continued availability of crop nutrients from organic and inorganic nutrient sources might have improved grains spike $^{-1}$. Arif et al. (2006) reported that joint application of organic and mineral sources of crop nutrients enhanced grains spike $e^{-1}$ and they attributed this to the slow release of plant nutrients from decomposition of organic manure maintaining continuous availability of plant nutrients during the crop growth period.

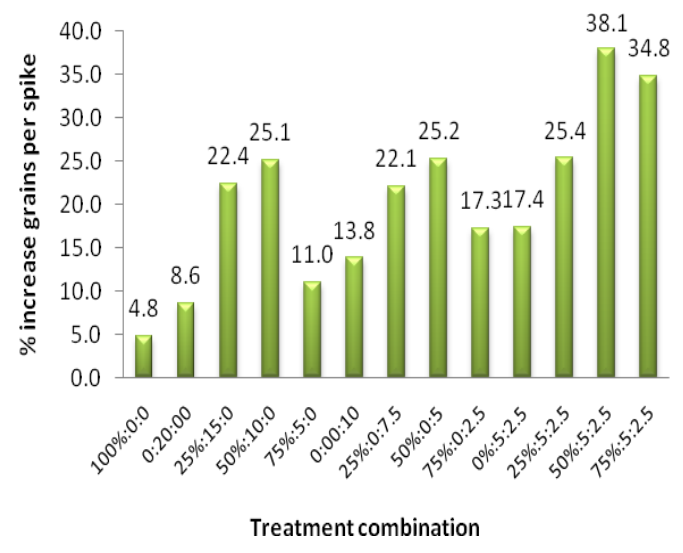

Figure 2: Percent increase in grain spike $^{-1}$ over control due to applied treatments

\section{Grain yield}

Combined use of organic and inorganic nutrient sources had significantly improved grain yield (Table 2). Higher grạin yield (4206 kg ha ${ }^{-1}$ ) was produced with the integrated application of 50\%:5:2.5 combination of NPK:FYM:PM as compared with minimum grain yield $\left(2211 \mathrm{~kg} \mathrm{ha}^{-1}\right)$ in control plot. The joint use of organic and mineral nutrient sources increased the grain yield by $90 \%$ over the control (Figure 3.). The results obtained are in line with Pooran et al. (2002), who reported that significantly higher grain yield was produced on plots that were more fertile with proper water availability and better crop management practices. The application of organic manure might have improved soil nutrient holding capacity and boosted nutrients availability. Application of inorganic fertilizer have improved crop yield and growth rate (Rani et al., 2001) whilst the decomposing organic manures might have served for nutrients availability at the later growth 
stages of the crop resulting in higher grain yield from the treatment plots.

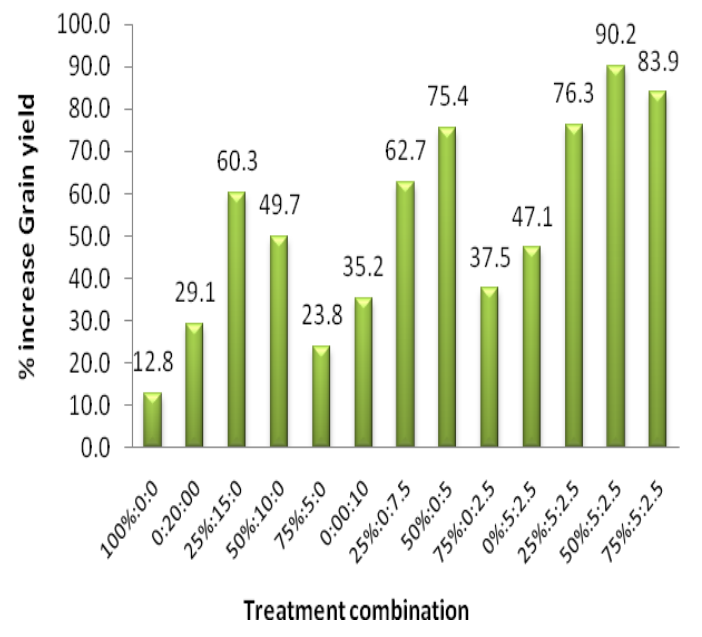

Figure 3: Percent increase in grain yield over control due to applied treatments
Ahmad et al. (2014) who investigated that application of organic manure alone or its combination with inorganic fertilizers had significantly improved soil bulk density, enhanced soil porosity and soil condition due to the dilution of soil body with the application of organic matter. Similar results were also obtained by Tejada et al. (2009) and Ahmad et al. (2017).

\section{Available water holding capacity}

Joint use of organic and inorganic nutrient sources had significantly enhanced șoil available water holding capacity (Table.3). Application of 0\%:20:0 combination of NPK:FYM:PM resulted in higher soil available water (22\%), followed by application of 25\%:15:0 combination of NPK:FYM:PM. Application of 50\%:5:2.5 combination of NPK:FYM:PM had improved soil available water as compared to control plot. Addition of organic matter had improved soil porosity and aggregation, which might have enhanced soil water holding capacity. These results are supported by Adeleye et ạl. (2010), Ahmad et al. (2014) and Ahmad et al. (2017) who stated that addition of organic matter either alone or in combination with

Table 3: Effect of integrated plant nutrient management on soil bulk density, saturation percentage and available water holding capacity (awhe)

\begin{tabular}{|c|c|c|c|c|}
\hline $\begin{array}{l}\text { Treatment } \\
\text { (NPK:FYM:PM) }\end{array}$ & $\begin{array}{l}\text { Bulk density } \\
\left(\mathrm{g} \mathrm{cm}^{-3}\right)\end{array}$ & AWHC (\%) & Saturation (\%) & $\begin{array}{l}\text { Soil organic matter } \\
(\%)\end{array}$ \\
\hline $0: 0: 0$ & $1.43 \mathrm{a}$ & $13.9 \mathrm{~g}$ & $34.1 \mathrm{~g}$ & $0.63 \mathrm{~d}$ \\
\hline 100\%:0:0 & $1.40 \mathrm{ab}$ & $14.2 \mathrm{f}$ & $36.2 \mathrm{fg}$ & $0.81 \mathrm{~cd}$ \\
\hline $0: 20: 0$ & $1.28 \mathrm{~d}$ & $21.9 \mathrm{a}$ & $51.4 \mathrm{a}$ & $1.42 \mathrm{a}$ \\
\hline $25 \%: 15: 0$ & $1.29 \mathrm{~d}$ & $20.6 \mathrm{~b}$ & $48.8 \mathrm{ab}$ & $1.36 \mathrm{a}$ \\
\hline $50 \%: 10: 0$ & $1.31 \mathrm{~cd}$ & $19.0 \mathrm{c}$ & $45.9 \mathrm{bc}$ & $1.12 \mathrm{abc}$ \\
\hline $75 \%: 5: 0$ & $1.33 \mathrm{~cd}$ & $17.1 \mathrm{~d}$ & $43.2 \mathrm{~cd}$ & $1.04 \mathrm{abcd}$ \\
\hline $0: 0: 10$ & $1.29 \mathrm{~d}$ & $18.9 \mathrm{c}$ & $45.7 \mathrm{c}$ & $1.42 \mathrm{a}$ \\
\hline $25: 0: 7.5$ & $1.30 \mathrm{~d}$ & $18.9 \mathrm{c}$ & $45.4 \mathrm{c}$ & $1.21 \mathrm{abc}$ \\
\hline $50 \%: 0: 5$ & $1.34 \mathrm{~cd}$ & $17.0 \mathrm{~d}$ & $40.4 \mathrm{de}$ & $1.02 \mathrm{abcd}$ \\
\hline $75 \%: 0: 2.5$ & $1.36 \mathrm{bc}$ & $16.3 \mathrm{e}$ & 38.8 ef & $0.90 \mathrm{bcd}$ \\
\hline $0: 5: 2.5$ & $1.32 \mathrm{~cd}$ & $18.9 \mathrm{c}$ & $45.1 \mathrm{c}$ & $1.11 \mathrm{abc}$ \\
\hline $25 \%: 5: 2.5$ & $1.31 \mathrm{~cd}$ & $19.1 \mathrm{c}$ & $45.4 \mathrm{c}$ & $1.29 \mathrm{ab}$ \\
\hline $50 \%: 5: 2.5$ & $1.30 \mathrm{~d}$ & $19.1 \mathrm{c}$ & $46.2 \mathrm{bc}$ & $1.32 \mathrm{ab}$ \\
\hline $75 \%: 5: 2.5$ & $1.31 \mathrm{~cd}$ & $19.1 \mathrm{c}$ & $45.4 \mathrm{c}$ & $1.32 \mathrm{ab}$ \\
\hline $\mathbf{L S D}_{(p \leq 0.05)}$ & 0.06 & 0.29 & 3.08 & 0.44 \\
\hline
\end{tabular}

\section{Soil bulk density}

Joint use of organic and inorganic nutrient sources had significantly improved soil bulk density (Table 3). Lower soil bulk density $\left(1.28 \mathrm{~g} \mathrm{~cm}^{-3}\right)$ was recorded with application of 0:20:0 combination, followed by $25 \%: 15: 0$ combination of NPK:FYM:PM while higher soil bulk density $\left(1.43 \mathrm{~g} \mathrm{~cm}^{-3}\right)$ was observed in control plots. The results are in accordance with Shirani et al. (2002) and inorganic fertilizers had improved șoil water holding capacity due to its efficient water absorbing ability. The hydrophobic and colloidal nature of organic manure might be the probable reason of improved water holding capacity of soil (Mbah and Mbagwu, 2006).

\section{Saturation percentage}

Application of organic manures had significantly improved soil saturation percentage (Table 3). The highest 
saturation percentage (51\%) was observed with application of 0\%:20:0 combination of NPK:FYM:PM, followed by the application of 25\%:15:0 combination of NPK:FYM:PM. Addition of 50\%:5:2.5 combination of NPK:FYM:PM resulted in higher percent saturation as compared to control plot (34\%). Application of organic manure had improved soil bulk density and enhanced soil porosity. The findings are in accordance with Khan et al. (2007) who described that addition of organic matter had improved soil bulk density and porosity. Haynes and Naidu (1998) have reported similar results.

\section{Soil organic matter}

Soil organic contents significantly improved with application of organic manure alone or in combination with inorganic fertilizer over control treatment (Table 3). The plot which were treated with 0:20:0, 0:0:10 combination of NPK: FYM: PM resulted in high organic matter content $1.42 \%$ and $1.36 \%$, respectively, followed by the use of 50\%:5:2.5 mixture of NPK: FYM: PM.

The control treatment was lower content of soil organic matter (0.63). The results are supported by the finding of Blair et al. (2006) who concluded that use of organic manure alone or in combination with chemical fertilizer improved physical properties and organic matter content of soil. The probable reason may be due to increases of microbial activity which decomposes organic manure and increases organic matter content in soil (Marschner, 2011).

\section{Correlation of organic matter with soil parameters}

Negative correlation of soil organic matter with bulk density ( $r=-0.96$, Figure 4) while positive correlation with percent available water (Figure 5), and saturation (Figure 6), was found. Organic amendments improved bulk density, total porosity, percent saturation and available water (Wiqar. 2009).

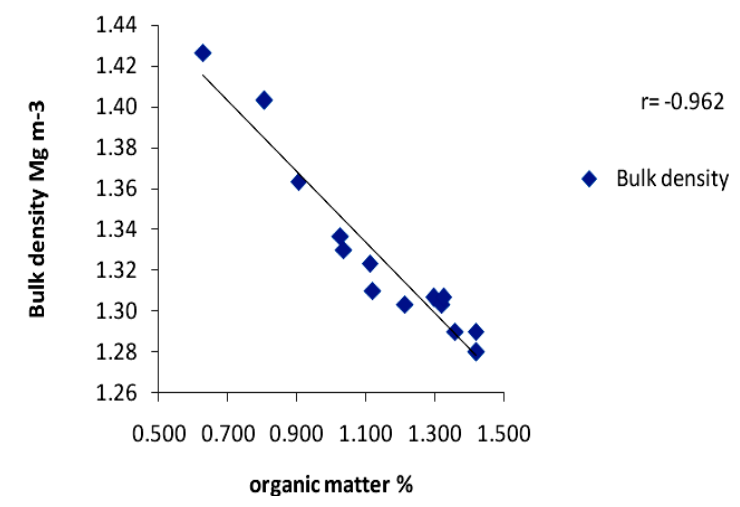

Figure 4: Relationship between soil organic matter and bulk density

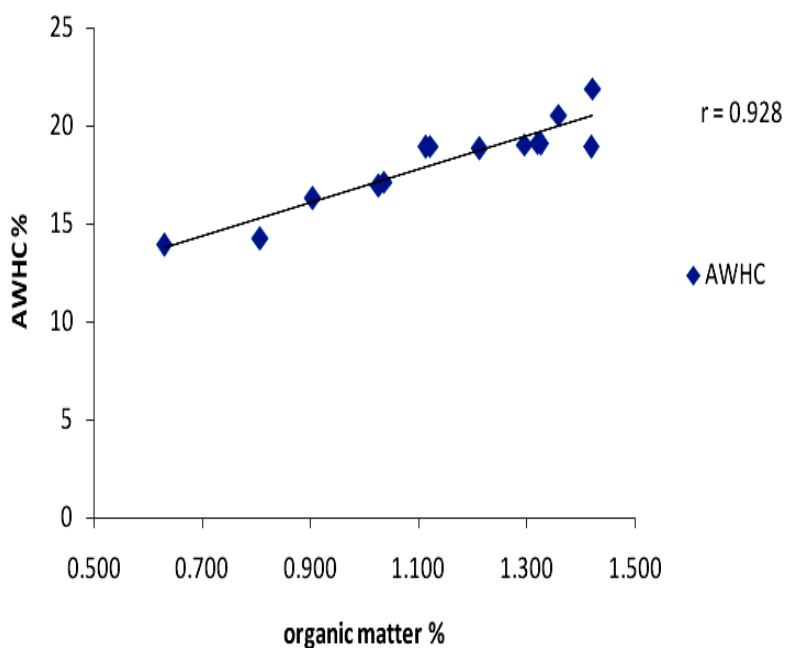

Figure 5: Relationship between soil organic matter and percent available water

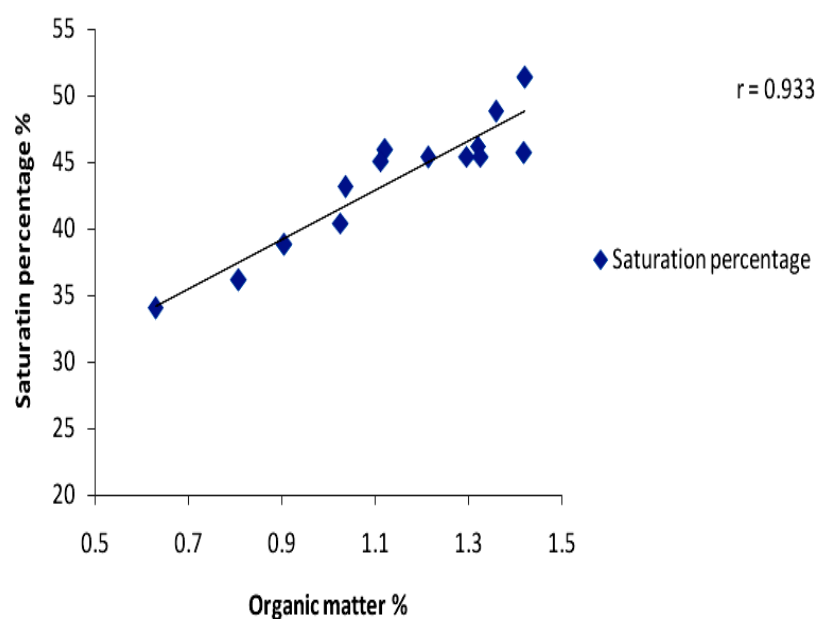

Figure 6: Relationship between soil organic matter and percent saturation

\section{Conclusion}

From this investigation, it can be concluded that combined use of organic and synthetic fertilizers significantly improved crop yield and șoil physical properties over the recommended levels of NPK fertilizers alone. Therefore, integrated sources of plant nutrients application should be carried out for sustainable farming on such water eroded land. The current study found 50\%:5:2.5 combination of NPK: FYM: PM as the best combination of nutrients sources for restoring soil physical properties and yield of the soil affected by water erosion. 


\section{References}

Adeleye, EO, L.S., Ayeni, and S.O. Ojeniyi. 2010. Effect of poultry manure on soil physico-chemical properties, leaf nutrient contents and yield of yam (Dioscorearotundata) on alfisol in southwestern Nigeria. Journal of American Science 6:871-878.

Ahmad, W. and F. Khan. 2014. Remediation of soil past erosion effects through amendments and agronomic practices. Journal of National Science Foundation of Sri Lanka 42(1):45-62.

Ahmad, W., F. Khan and M. Naeem. 2014. Improvement in physical properties of eroded agricultural soil through agronomic management practices. Indian Journal of Agriculture Science 84(7): 850-855.

Ahmad, W., Farmanullah, Z. Shah, M. Jamal and K. A. Shah. 2014. Recovery of organic fertility in degraded soil through fertilization and crop rotation. Journal of the Saudi Society of Agricultural Sciences 13(2):92-99. https://doi.org/10.1016/j.jssas.2013.01.007 Accessed on.

Ahmad, W., Farmanullah, Z. Shah and M. J. Khan. 2017. Changes in quality and yield potential of moderately degraded Alfisol with types and levels of nutrient input and legumes in crop rotation. Pedosphere, published online; DOI 10.1016/S1002-0160 (17) 60364-3

Ali. S., A.U. Bhatti, K. Farmanullah and A. Ghani. 2007. Performance of mung-bean in wheat mung- bean system under integrated plant nutrient management on eroded lands. Sarhad Journal of Agriculture 24(3):445452.

Allen, R,A. 1991. Soil conservation activities undertaken for the Dir District Development Project: An evaluation and proposals for the future. UNDP.

Arif, M., S. Ali., A. Khan., T. Jan and M. Akbar. 2006. Influence of farmyard manure application on various wheat cultivars. Sarhad Journal of Agriculture 22: 2729.

Banning, N.C., C.D. Grant, D.L. Jones and D.V. Murphy. 2008. Recovery of soil organic matter, organic matter turnover and nitrogen cycling in a post-mining forest rehabilitation chronosequence. Soil Biology \& Biochemistry 40(8):2021-2031.

Bhatti, A. U. 2006. Restoring crop productivity of eroded lands through integrated plant nutrient management (IPNM) for sustained production. Final technical Report2003-2006, Pakistan Science Foundation Research Project, Department of Soil and Environmental Sciences, NWFP Agriculture University Peshawar, Pakistan.

Bhatti, A. U. and M. A. Zahid. 1998. Soil properties and wheat yield as affected by soil erosion in a Palouse silt loam soil of Eastern Washington, USA. Pakistan Journal of Soil Science 15:21-25.

Blair, N., R.D. Faulkner, A.R. Till, P. Poulten. 2006. Longterm management impacts on soil $\mathrm{C}, \mathrm{N}$ and physical fertility. I. Broadbalk experiment. Soil and Tillage Research 91, 30-38.

Blake, G.R. and K.H. Hartage. 1984. Bulk density. p 364-6. In: Methods of Soil Analysis. Part 1, G.S. Campbell, R.D. Jackson, M.M. Marttand, D.R. Nilson and A. Klute (eds.). American Society of Agronomy, Inc., Madison, WI, USA.

Gardner W H. 1986. Water content. p 383-411. In: Method of Soil Analysis. Part-1: Physical and Mineralogical Properties, A. Clute (ed). Agronomy Monograph No.9, American Society of Agronomy.

Haynes, R.J. and R. Naidu. 1998. Influence of lime, fertilizer and manure applications on soil organic matter content and soil physical conditions: a review. Nutrient Cycling in Agriculture Ecosystem and Environment 51: 123-137.

Idrees, M., M. Iqbal., S. M. Shah and W. Muhammad. 2002. The integrated effect of mineral and organic nitrogen and azobacterization on the yield and nitrogen nutrition of wheat. Pakistan Journal of Soil Science 20: 19-24.

Khan, F., W. Ahmad, A.U. Bhatti, R.A. Khattak and M. Shafiq. 2004. Effect of soil erosion on chemical properties of some soil series in NWFP, Pakistan. Science Technology and Development 23(4): 31-5.

Khan, F., A.U. Bhatti and R.A. Khattak. 2001. Soil and nutrient losses through sediment and surface runoff under maize mono cropping and maize legume intercropping from upland sloping field. Pakistan Journal Soil Science 19:32-40.

Khan, M.U., M. Qasim and Israr Ullah Khan. 2007. Effect of integrated nutrient management on crop yields in rice-wheat cropping system. Sarhad Journal of Agriculture Vol. 23, No. 4.

Marschner, P. 2011. Marschner's Mineral Nutrition of Higher Plants. 3rd Ed. London: Academic Press.

Mbah, C. N. and J.S.C. Mbagwu. 2006. Effect of animal wastes on Physico-chemical properties of a dystric Leptosol and maize yield in southern Nigeria. Nigerian Journal of Soil Science 16: 96- 103.

Mussgnug, F., M. Becker, T.T. Son, R.J. Buresh and P.L.G. Vlek. 2006. Yield gaps and nutrient balances in intensive, rice-based cropping systems on degraded soils in the Red River Delta of Vietnam. Field Crops Research 98(2-3): 127-40.

Pooran, C., P. K. Singh., M. Govardhan and P. Chand. 2002. Integrated management in rainfed castor (Ricinus communis). Indian Progressive Agriculture 2: 122-124. 
Rani, R., O. P. Srivastava and R. Rani. 2001. Effect of integration of organics with fertilizer $\mathrm{N}$ on rice and $\mathrm{N}$ uptake. Fertilizer News 46: 63-65.

Raza, S.J., A.U. Bhatti, M. Rashid and F. Khan. 2003. Developing moisture release curves of soil of rainfed area using suction upto $0.1 \mathrm{Mpa}$. Pak Journal of Soil Science 22 (3): 17-23.

Shirani, H., M.A. Hajabbasi, M. Afyuni and A. Hemmat. 2002. Effect of farm manure and tillage systems on soil physical properties and corn yield in central Iran. Soil and Tillage Research 68:101-108.

Steel, R. G. D., J. H. Torrie and D. A. Dickey. 1997. Principles and Procedures of Statistics. A Biometrical Approach, 3rd Ed. McGraw Hill Book Company, New York, 172-177.
Tagar, S. and A.U. Bhatti. 1996. Soil physical properties. In: Soil Science, p 250. Elena Bashir and Robin Bantel (Ed). National Book foundation, Islamabad.

Tejada, M., M. T. Hernandez. and C. Garcia. 2009. Soil restoration using composted plant residues: Effects on soil properties. Soil and Tillage Research 102: 109-117.

UN. 2008. World Population Prospects: The 2008 Revision, Volume III. United Nations Department of Economic and Social Affairs, New York.

Wiqar, A. 2009. Managing soil fertility for sustained crops productivity on eroded lands of district Swabi. PhD. Thesis. Department of Soil and Environmental Sciences, The University of Agriculture, PeshawarPakistan. 